\title{
Segurança e construção da paz na América do Sul: os desafios apontados pela Upsalla Conflict Data Program e The Fund for Peace*
}

\author{
Security and the peacebuilding in South America: \\ the challenges faced by Upsalla Conflict Data Pro- \\ gram and The Fund for Peace*
}

\section{COMPREENDENDO O CONFLITO PELO VIÉS DA PAZ: ASPECTOS CONCEITUAIS E TEÓRICOS PROPOSTOS POR JOHAN GALTUNG}

Uma das principais contribuições do pensamento do norueguês Johan Galtung para os estudos de segurança está na compreensão do conceito de paz, em contraposição a uma abordagem focalizada na questão da violência propriamente dita. Galtung a define como "a ausência de violência e como um movimento contrário a qualquer tipo de violência, desta forma a paz só poderá ser alcançada através da total compreensão dos problemas onde haja o envolvimento da violência” (CIIIP apud Serbín 2006, 17).

A vantagem apresentada por Grewal (2003) a respeito do conceito de violência de Galtung é que a definição é muito mais ampla do que a defi-

\footnotetext{
* Esse artigo é apresenta resultados parciais do projeto de pesquisa "O desafio da paz na América do Sul: as perspectivas de entidades de análise de conflitos e a atuação da UNASUL frente aos litígios potenciais", financiado pelo Edital 14/2013 do CNPq (Conselho Nacional de Desenvolvimento Científico e Tecnológico). Agradecemos aqui o trabalho de revisão técnica de Natália Silvestre.

** Professor Adjunto do Departamento de Relações Internacionais na Universidade Federal da Paraíba (UFPB). Contato: marcosalan@gmail.com

*** Bolsista de Iniciação Científica CNPq/PIBIC e graduando em Relações Internacionais pela Universidade Federal da Paraíba. Contato: pedropaulodasilvajr@gmail.com

**** Scientific Research Scholarship receiver from CNPq and Postgraduate student in MSc in Political Science at the Universidade Federal do Rio Grande do Sul (UFRGS).
} 
nição comum, considerando esta apenas como somática ou direta, e ainda inclui a violência estrutural. Ela leva a uma definição ampliada de paz, esta não sendo apenas uma ausência da violência direta (paz negativa), mas também a ausência da violência estrutural (a paz positiva). Ou seja, permite diferenciar os tipos de violência e escapar de um conceito linear e unidimensional da paz, pois evita a existência de um tipo ideal de violência a partir da identificação de espaços de violência construídos historicamente pelas sociedades. Isso leva à produção de um conceito aproximado de paz, tendo como base a violência dividida em termos de realização e potencialidades (Serbín 2006).

Um ponto importante ressaltado por Grewal é que, apesar das ideias apresentadas por Galtung serem bastante reconhecidas nos estudos de paz, existem os críticos da mesma. As principais críticas são feitas por teóricos pós-modernistas, que criticam os valores de paz baseando-se em dados empíricos de violência direta. Além disso, as ideias galtungianas atuam como contrapeso à teoria realista das relações internacionais, na qual o Estado é o principal ator dessas relações. Grewal afirma que, mesmo a teoria de paz sendo construtivista por natureza, Galtung rejeita a epistemologia positivista, preferindo adotar uma visão mais eclética, isto é, combinando as filosofias ocidentais e orientais em seus conceitos e suas teorias (Grewal 2003).

É com esse pensamento que o autor também nos proporciona uma abordagem mais ampla em torno da questão do que é segurança e paz. Promovendo uma contraposição entre os estudos baseados em segurança, de um lado, e na construção da paz, de outro, ele nos permite ver diferenças discursivas que podem permitir uma compreensão mais ampla de problemas complexos, tal como vemos na América do Sul e na sua situação de violência social.

A abordagem de segurança, segundo Galtung (1969), é baseada em quatro componentes: 1) uma parte com uma forte capacidade e intenção maligna; 2) um claro e presente perigo de violência, real ou potencial; 3) força, para impedir ou derrotar a parte maligna, gerando assim 4) segurança, esta que seria a melhor abordagem para paz. Essa abordagem funcionará quando a 'parte maligna' estiver fraca através do impedimento ou derrota e/ou conversão desta parte para uma que seja boa. A abordagem de segurança também pressupõe força superior que implicará em desigualdade e superioridade (Galtung 1969).

Já a abordagem de paz toma um rumo diferente, baseando-se também 
em quatro componentes, a saber: 1) um conflito que não foi resolvido ou transformado; 2) um perigo de violência que pode se transformar num conflito "que tenha que ser resolvido de uma vez por todas"; 3 ) a transformação do conflito de forma empática-criativa e não violenta, gerando assim 4) paz, esta que seria a melhor abordagem para segurança. A abordagem de paz também pressupõe um resultado aceitável do conflito para todas as partes, implicando igualdade e paridade nesse processo (Galtung 1969).

Por fim, Galtung (1969) cita os argumentos que favorecem as duas abordagens. $\mathrm{O}$ argumento da abordagem de paz contra a abordagem de segurança é forte. De acordo com essa visão, a abordagem de segurança funciona como uma bandagem sobre uma ferida profunda. Segundo a abordagem de paz, a formação conflituosa das partes com objetivos muito incompatíveis deve ser transformada numa formação pacífica através da construção de objetivos legítimos não violentamente, empaticamente e criativamente. Um conflito não transformado reproduzirá mais violência cedo ou tarde (Galtung 1969).

Já o argumento da abordagem de segurança contra a abordagem de paz também é forte. Segundo essa visão, nem todas as partes são guiadas por valores legítimos; alguns são guiados por uma ganância ilegítima. O perigo deve ser parado antes que ele destrua todas as partes. Depois de uma transformação pacífica do conflito, a ganância pode ameaçar a todos, não produzindo nem segurança e nem paz (Galtung 1969).

Diante desse contexto, como podemos pensar a atual situação da América do Sul? Ainda que no caso sul-americano a abordagem da segurança seja a mais usada, nota-se que transformar a região em pacífica vai além de considerar os conflitos que nela existem como uma guerra entre o "eu" e o "outro". Os temas que afligem a segurança sul-americana giram em torno do narcotráfico, tráfico de armas e atentados contra a vida atrelados a uma desigualdade social que é crescente e não pode ser negligenciada. Mais que uma ameaça constante de guerra entre Estados, a ameaça contra a vida por parte de facções criminosas, gangues e narcotraficantes são temas que afligem praticamente toda a América do Sul e geram uma violência estrutural que merece ser debatida com cautela antes de qualquer diagnóstico precoce.

Para pensarmos um pouco sobre essas problemáticas, apresentaremos em seguida como duas importantes entidades de análise de conflitos e risco político enxergam a América do Sul. Veremos que, embora o número de conflitos interestatais - categorizados pela Upsalla Conflict Data Program- 
seja pequeno para os últimos seis anos, a violência estrutural permanece e afeta o Estado, como demonstra The Fund for Peace.

\section{AS PERCEPÇÕES DA UPSALLA CONFLICT DATA PROGRAM SOBRE OS PADRÕES DE CONFLITIVIDADE NA AMÉRICA DO SUL}

A base de dados Uppsala Conflict Data Program (UCDP), pertencente ao Department of Peace and Conflict Research da Universidade de Uppsalla (Suécia), é considerada uma referência mundial nos estudos de paz e guerra. A UCDP registrou vários conflitos violentos desde os anos 1970, e seus dados permitem análises precisas sobre conflitos armados mundiais.

Caracterizamos aqui os países sul-americanos de acordo com as definições da UCDP. As categorias retiradas da UCDP são: 'War E̊ minor conflict' (Guerra e conflito menor), 'Non-state conflict' (Conflito não estatal) e 'One-sided violence’ (Violência unilateral).

Segundo a UCDP, apenas a Colômbia, o Peru e a Guiana apresentariam uma conflitividade de maior intensidade nos últimos anos. Como demonstrado pela tabela 1, na sua maioria são conflitos menores focados, mormente presentes no Estado colombiano.

Tabela 1: Tipos de conflitos na América do Sul segundo a UCDP (2006-2011)

\begin{tabular}{|c|c|c|c|}
\hline ANOS & $\begin{array}{c}\text { GUERRA E } \\
\text { CONFLITO MENOR }\end{array}$ & $\begin{array}{c}\text { CONFLITO } \\
\text { NÃO ESTATAL }\end{array}$ & $\begin{array}{c}\text { VIOLÊNCIA } \\
\text { UNILATERAL }\end{array}$ \\
\hline 2006 & Colômbia & $\mathrm{x}$ & Colômbia \\
\hline 2007 & Colômbia e Peru & $\mathrm{x}$ & $\mathrm{x}$ \\
\hline 2008 & Colômbia e Peru & $\mathrm{x}$ & Colômbia e Guiana \\
\hline 2009 & Colômbia e Peru & $\mathrm{x}$ & Colômbia \\
\hline 2010 & Colômbia e Peru & $\mathrm{x}$ & Colômbia \\
\hline 2011 & Colômbia & $\mathrm{x}$ & $\mathrm{x}$ \\
\hline
\end{tabular}

Fonte: Realizado pelos autores com base nos dados da UCDP. Disponível em <http://www. ucdp.uu.se/gpdatabase/gpregions.php?regionSelect=5-Southern\%20Americas>

Um ponto válido a acrescentar na análise da UCDP é a pouca participação dos países sul-americanos em conflitos, o que, a princípio, pode levar a crer que esta região seria pacífica. 
A definição de War $\mathscr{E}^{2}$ Minor Conflict (Guerra e conflito menor) se caracteriza como o conflito armado direto existente ou já finalizado entre dois ou mais Estados, sendo esses conflitos de baixa intensidade (conflitos intraestatais) ou de alta intensidade (conflitos interestatais). Percebe-se nesta categoria uma grande participação da Colômbia e do Peru nos anos estabelecidos (Uppsala University 2013). A UCDP lembra que surgiram na Colômbia, em meados dos anos 1960, vários grupos de esquerda como as FARC, ELN, EPL e M-19, que iniciaram uma luta armada contra o governo. De acordo com a base dados, ambos os lados têm os civis como alvo, mas ao mesmo tempo eles também afirmam que estão em defesa destes (Uppsala University 2013). O caso colombiano é bastante interessante pelo fato de sua violência se encaixar como exemplo de 'Guerra e conflito menor' e ao mesmo tempo de 'Violência unilateral'. Por isso, mais adiante será explicado com maiores detalhes como se dá a participação do governo e dos grupos paramilitares na última seção.

A respeito do Peru, pode-se dizer que o mesmo também se encaixa nessa categoria de violência, pois a UCDP coloca que houve divisões entre os grupos da população, contribuindo para o surgimento de vários grupos guerrilheiros de orientação política esquerdista durante o século 20. Ocorreram conflitos intraestatais, entre o governo e esses grupos políticos, durante os anos 1950 e 1960, tendo como principal motivação a distribuição desigual de terra. De 1960 até os anos 1980, uma junta militar impôs algumas reformas agrárias no país, que foram consideradas insatisfatórias pelos grupos de oposição esquerdistas, contribuindo assim para um novo conflito intraestatal entre governo e grupos de esquerda, iniciado em 1981 e finalizado em 1999, e voltando a ser ativo novamente em 2007.

Com a captura de um dos líderes fundadores desses grupos, o Sendero Luminoso (SL), o grupo acabou se tornando ideológica e geograficamente dividido. Florindo Eleuterio Flores Hala, conhecido como Camarada Artemio, tornou-se líder do SL com a captura de Abimael Guzmán e anunciou em 2011 que a luta armada havia se encerrado, mas que a sua luta política iria continuar. No entanto, a presença militar do SL ainda preocupa o governo peruano e persiste em áreas rurais do país. Outro dado citado sobre esse país é o fato de que em 1995 o Peru e o Equador travaram um breve conflito devido a problemas de demarcação de fronteiras na área da Cordilheira do Condor. Após algumas semanas foi assinado um cessar-fogo mediado pelo Brasil, e, embora as tensões entre os dois países ainda fossem crescentes, em 1998 foi assinado um acordo de paz pelos dois lados 


\section{(Uppsala University 2013).}

A categoria Non-state conflict (Conflito não estatal) é definida como o uso da força armada entre dois grupos armados organizados sem que os mesmos pertençam ao governo de um Estado. Esse tipo de violência, de acordo com a UCDP, resulta no mínimo em 25 mortes no período de um ano. O detalhe mais interessante nesta seção é que se vê uma participação nula dos países da América do Sul (Uppsala University 2013).

One-sided violence (Violência unilateral) é caracterizado como o uso da força armada por parte de um dos governos dos Estados ou por um grupo organizado formalmente contra civis. Este tipo de violência, de acordo com o UCDP, também resulta em pelo menos 25 mortes no período de um ano execuções extrajudiciais em instalações do governo, porém, são excluídas dessa categoria. Nota-se nesta categoria novamente uma grande participação da Colômbia, só que agora com uma pequena participação da Guiana (Uppsala University 2013). A UCDP cita que o governo da Colômbia vem se envolvendo em conflitos intraestatais com diferentes grupos armados desde o período turbulento conhecido como "La Violência", e nesse intervalo de tempo o Estado teria cometido atos de violência unilateral contra os civis. Segundo organizações de direitos humanos, essa violência seria um disfarce do fracasso do governo colombiano na distinção entre civis e combatentes (Uppsala University 2013). Além disso, o governo é acusado frequentemente de colaborar com grupos paramilitares - também conhecidos como paras - criados nos anos 1980 por grandes proprietários de terras e traficantes de drogas. Tais grupos foram pensados com o objetivo de combater a guerrilha de esquerda do ELN e das FARC. Os paras também têm gerado violência contra civis em áreas nas quais a dominação das guerrilhas seria fraca. Em suma, para estes atos o governo teria, além do apoio dos paramilitares, também o apoio de militares e policiais (Uppsala University 2013).

Já sobre os guerrilheiros colombianos, estes cresceram cada vez mais devido a sequestros rentáveis e ao comércio ilegal de drogas. Houve tentativas de influenciar as decisões tomadas pelo governo por meio de ataques tendo como alvos funcionários do governo ou civis. Nesse ponto, as FARC (Fuerzas Armadas Revolucionarias de Colombia) possuem um papel de destaque, pois, dos grupos de guerrilheiros que participaram de conflitos intraestatais contra o governo, este foi o que ganhou mais importância.

Quanto à Guiana: segundo a UCDP, o problema que este Estado enfrenta e que o enquadra na categoria de Violência Unilateral é a existência da 
gangue de Buxton, grupo envolvido em inúmeros sequestros, assassinatos e roubos entre a população guianense desde 2002. Em 2006 essa gangue assassinou o Ministro da Agricultura Satyadeow Sawh; em 2008, entrou em confronto com a polícia e atacou civis numa escala ainda maior do que os anos anteriores, resultando em pelo menos 29 mortes (Uppsala University, 2013).

A partir da visão da UCDP também se pode afirmar, à luz dos conceitos de Galtung, que haveria a predominância de uma paz negativa na América do Sul. Ou seja, mesmo não havendo um conflito armado direto de grandes proporções entre os Estados sul-americanos, a violência ainda possui uma forte presença nessa região. A violência estrutural estaria presente também no caso da Colômbia e do Peru, sendo gerada pelo violento contexto histórico-social que permeou sua história recente.

A respeito da abordagem da violência, também se percebe que, nos três casos, houve maior foco na resolução da violência através da abordagem de segurança, em lugar da abordagem pacífica. Este detalhe, de acordo com Galtung, não ajuda a resolver o problema da violência de maneira efetiva, e consequentemente, a alcançar a paz positiva.

\section{A BASE DE DADOS DA FUND FOR PEACE (FFP) E SUAS DEFINIÇÕES SOBRE A AMÉRICA DO SUL}

Segundo o Fund For Peace (2013), com o fim da Guerra Fria emergiram conflitos internos e violência em massa em diversos estados. Mesmo com as diferenças entre essas dinâmicas, elas são resultados de pressões sociais, econômicas e políticas que não foram administradas por instituições representativas legítimas. Os Estados fracos e falidos representam atualmente um grande desafio para a comunidade internacional, pois essas pressões exercidas em um Estado frágil podem criar graves efeitos não somente a esse Estado e a sua população, mas também a outros Estados participantes no cenário internacional (Fund For Peace 2013).

Também de acordo com o FFP, as falhas dos Estados fracos e falidos podem surgir devido a problemas de grupos de identidade, caracterizados pela língua, religião, nacionalidade, etnia e classe (Fund For Peace 2013). O 'Failed States Index' (Índice de Estados Falidos), criado pelo FFP, procura fazer uma avaliação além do conhecimento da área especializada, combinando interdisciplinarmente pesquisas qualitativas com metodologias quantitativas.

1. Para mais sobre a metodologia, ver FUND FOR PEACE (2013). 
Os indicadores são baseados nos campos social, econômico, político e militar (estes últimos são unidos numa mesma categoria), e ainda se subdividem em outras categorias ${ }^{1}$.

A posição ocupada por cada país sul-americano no FFP é determinada pela soma total das notas (estas variam de 1 a 10) dos subindicadores de cada uma das três categorias apresentadas anteriormente. Para os fins desse capítulo, será realizada uma análise de maneira geral, de acordo com os indicadores sociais, econômicos e político-militares (uma análise minuciosa de cada uma das categorias com cada Estado sul-americano estenderia demais o texto).

De acordo com a metodologia da FFP, quanto mais baixa for a posição de um país no ranking, maior será sua segurança; a pontuação baixa nos três indicadores indica que o país apresenta poucos ou quase nenhum problema desse tipo.

Nos anos de 2006 a 2009, com exceção da Guiana e do Suriname, que não tiveram seus dados registrados, percebe-se que a maior parte dos países sul-americanos são caracterizados pelo FSI como próximos da categoria "Warning" (exceto a Colômbia, que é enquadrada nesta categoria), sendo considerados mais seguros apenas a Argentina, o Uruguai e o Chile, que estão na categoria "Moderate". Com isso, pode-se dizer, a princípio, que a região sul-americana durante esse período possuía uma alta taxa da violência - principalmente a do tipo estrutural, de acordo com a visão de Galtung.

De acordo com os indicadores sociais, nota-se uma variação bem perceptível entre os países sul-americanos (com a nota mais baixa sendo 1,0 e a mais alta, 9,1). Vale destacar que Colômbia, Bolívia, Equador, Venezuela e Peru, os cinco primeiros colocados e presentes na categoria "Warning", são os que apresentavam maiores problemas desse tipo. Apesar de outros países aparecerem nessa categoria, percebe-se que o resultado dos outros indicadores contribuiu para que a posição ocupada de acordo com os indicadores sociais não fosse tão alta (por exemplo, Brasil e Paraguai).

Nos indicadores econômicos (UED e ECO), pode-se perceber que os cinco primeiros também apresentam bastantes desafios nessa área. Das três categorias, o campo econômico era o principal desafio a ser enfrentado pela região. Os cincos primeiros do ranking, além dos problemas sociais, mostravam grandes problemas com o desenvolvimento econômico.

Por fim, quanto aos indicadores político-militares neste campo, assim como com os indicadores sociais, há uma grande variação entre os países 
da região (com a nota mais baixa sendo 1,0 e a mais alta, 9,2). Apesar disso, é válido notar que a Colômbia e a Venezuela são os países que apresentam os maiores valores nessa categoria, o que corrobora com o fato de estes Estados serem conhecidos por seus problemas no campo político e principalmente militar.

Houve uma melhora nos indicadores econômicos em 2010, embora a variação do valor desta média em relação a 2009 tenha sido pequena. Os indicadores político-militares de 2010 também apresentaram melhorias em relação aos anos de 2006, 2007 e 2009. Quanto a 2008, segundo os indicadores, alguns países conseguiram melhorar seu desempenho, mas outros conseguiram piorá-los.

Por fim, sobre o ano de 2011 , não houve nenhuma mudança em relação a 2010. Quanto a seus indicadores, pode-se dizer o mesmo: os valores e seu desempenho são os mesmos do ano anterior.

\section{CONSIDERAÇÕES FINAIS: ANÁLISE COMPARATIVA DOS DADOS GERAIS DA UCDP E DA FUND FOR PEACE (FFP) À LUZ DOS CONCEITOS USADOS POR GALTUNG}

Como dito na introdução, os resultados aqui apresentados são preliminares de uma pesquisa em desenvolvimento. Não obstante, pode-se afirmar que, em relação a suas metodologias, fica claro que os métodos de análise da UCDP e da FFP diferem bastante. O primeiro se focaliza em conflitos armados quase que exclusivamente, enquanto a base da FFP abrange uma variedade maior de variáveis e consegue expor melhor a situação da América do Sul.

A respeito dos dados da FFP, eles, assim como os da UCDP, confirmam as visões de Medeiros (2008) e Alsina Jr. (2009) de que há uma instabilidade maior na região andina que vai do Peru até a fronteira Venezuela-Guiana. Entretanto, mesmo os países que estão no Arco de Estabilidade - em que se destaca o Cone Sul - não seriam seguros. A maior parte deles, de acordo com os anos selecionados (2006 a 2011), recebeu a categoria "Warning", o que significa que a região, na verdade, está no nível de Estados com dificuldade de institucionalização em algumas áreas e com sérias dificuldades para garantir a segurança de sua população.

Os dados da FFP, contudo, reforçam ainda mais o pensamento de Johan Galtung de predominância de uma paz negativa, mesmo que não ocorram conflitos entre esses Estados. Em outras palavras: mesmo que não seja 
constante o uso de violência direta entre Estados, há uma predominância da violência estrutural na região.

Os dados são importantes para nos mostrar que, mesmo em níveis diferentes, a América do Sul pode ser considerada uma região em que a violência é inerentemente estrutural, e que métodos que foquem o uso da abordagem de segurança não são suficientes para resolver este problema. Ao contrário: é através dos estudos de paz e da abordagem de paz que os problemas da região serão resolvidos, pois, como se nota pela metodologia da FFP, os campos social, econômico e político estão intimamente ligados, e os mesmos influenciam a existência da violência. 


\section{UNDERSTANDING CONFLICT THROUGH THE PEACE BIAS: CONCEPTUAL AND THEORETICAL ASPECTS AS PROPOSED BY JOHAN GALTUNG}

One of the main contributions on security studies that can be taken from Norwegian author Johan Galtung relies on his comprehension of peace and its concept, which opposes to an approach focused only on the violence matter. Galtung defines it as "the absence of violence and as a motion in opposition to any type of violence, thus peace can only be achieved through the complete comprehension of the problems where there is the involvement of violence"1 (CIIIP apud Serbín 2006, 17).

The advantage presented by Grewal (2003) towards Galtung's concept of violence is that the definition is largely wider than the common definition, considering the latter only as somatic and direct (immediate), and includes even the structural violence. It takes to an extended definition of peace, so it do not only means an absence of direct violence (negative peace), but it also means the absence of the structural violence (positive peace). In other words, that definition permits to differentiate the kinds of violence and to escape from a linear and one-dimensional concept of peace, since it avoids the existence of an ideal form of violence by identifying the spaces of violence constructed historically by the societies. This leads to an approximate concept of peace, based on violence separated in terms of realization and potentialities (Serbín 2006).

An important point emphasized by Grewal is that despise the broad acknowledgment of the ideas presented by Galtung towards the peace studies, there are several critics to it. The main criticisms are made by postmodernist theorists, who criticize the peace values by resorting to empirical data of direct violence. Moreover, the thoughts from Galtung act as a counterweight to the realist theory of international relations, in which the State is the main actor of these relations. Grewal affirms that even the theory of peace being constructivist by nature Galtung rejects the positivist epistemology. In that sense, Galtung prefers to adopt a more eclectic vision, combining the occidental and the oriental philosophies in its concepts and theories (Grewal 2003).

It is with this thought that the author also gives us a broader approach

1. Quote translated to English by the translator of this article. 
on the question of what is security and peace. By promoting a contrast between security based studies on one hand, and peacebuilding studies, on the other, he allows us to see discursive differences that may allow a wider understanding of complex issues, such as it can be seen in South America and its situation of social violence.

The security approach, according to Galtung (1969), is based in four components: 1) an evil party, with strong capability and evil intention; 2) a clear and present danger of violence, real or potential; 3) strength, to deter or defeat the wicked party, in turn producing 4) security, which would be the best approach to peace. This approach works when the 'evil party' is weakened through defeat or deterrence, and/or conversion of this part to one that is good. The security approach also presupposes superior strength that will imply inequality and superiority (Galtung 1969).

The Peace Approach is also based on four components: 1) a conflict, which has not been resolved or transformed; 2) a danger of violence that might settle that conflict as one "that must be solved once and for all"; 3) the conflict transformation into empathic-creative-nonviolent, thus producing 4) peace, which would be the best approach to security. The peace approach also presupposes a conflict outcome acceptable to all parties, which implies equality and parity in this process (Galtung 1969).

At last, Galtung (1969) mentions the arguments that favor both of the approaches. The peace approach argument against the security approach is strong. According to this perception, the security approach serves like a bandage over a festering wound. In relation to the peace approach, the parties' quarrelsome shaping and their highly incompatible goals must be transformed into a pacific shaping through the construction of empathiccreative-nonviolent legitimate goals. An untransformed conflict will reproduce further violence sooner or later (Galtung 1969).

The security argument against the peace approach is also strong. In accordance with this perspective, not all parties are driven by legitimate grievances, some are driven by illegitimate greed. The danger has to be stopped before it destroys all parties. After a peaceful conflict transformation the greedy might threaten everyone else, which means it will produce neither security nor peace (Galtung 1969).

Given this context, how can the current situation in South America be thinked over? Although the security approach is the most used in the South American scenario, one may note that turning the region into peaceful goes beyond considering the conflicts that in there exist as a war between the "self" and the "other". The issues that afflict the South American 
security revolve around drug trafficking, arms trafficking and attempted murder linked to a growing social inequality that cannot be neglected. More than a constant threat of war between states, the threat against life made by criminal factions, gangs and drug traffickers is an issue that distresses almost all South America and that generates a structural violence that should be discussed carefully before any early diagnosis.

To reflect a little about these questions, it is subsequently presented how two important entities in conflict analysis and political risk sight South America. We will see that, although the number of interstate conflicts - as categorized by the Upsalla Conflict Data Program - might be small for the last six years, structural violence remains and affects the state, as demonstrated by The Fund for Peace.

\section{THE UPPSALA CONFLICT DATA PROGRAM PERCEPTIONS ON CONFLICT PATTERNS IN SOUTH AMERICA}

The Uppsala Conflict Data Program (UCDP) is a database that belongs to the Department of Peace and Conflict Research at the Uppsala University (Sweden). It is considered a worldwide reference in terms of peace and war studies. The UCDP has registered many violent conflicts since the 1970 s and its data has permitted precise analyses on world's armed conflicts.

The South American countries are here categorized according to the definitions of the UCDP. The categories taken from the UCDP are: War $\mathcal{E}^{\circ}$ minor conflict, Non-state conflict, and One-sided violence. As stated by the referred database, only Colombia, Peru and Guyana would present a conflict pattern considered as very intense in recent years. As shown in Table 1, conflicts are mostly focused mainly in the Colombian state.

Table 1: Types of conflicts in South America according to UCDP (2006-2011)

\begin{tabular}{|c|c|c|c|}
\hline YEARS & $\begin{array}{c}\text { WAR \& MINOR } \\
\text { CONFLICT }\end{array}$ & $\begin{array}{c}\text { NON-STATE } \\
\text { CONFLICT }\end{array}$ & $\begin{array}{c}\text { ONE-SIDED } \\
\text { VIOLENCE }\end{array}$ \\
\hline 2006 & Colombia & $\mathrm{x}$ & Colombia \\
\hline 2007 & Colombia e Peru & $\mathrm{x}$ & $\mathrm{x}$ \\
\hline 2008 & Colombia e Peru & $\mathrm{x}$ & Colombia e Guyana \\
\hline 2009 & Colombia e Peru & $\mathrm{x}$ & Colombia \\
\hline 2010 & Colombia e Peru & $\mathrm{x}$ & Colombia \\
\hline 2011 & Colombia & $\mathrm{x}$ & $\mathrm{x}$ \\
\hline
\end{tabular}

Source: Arranged by the authors based on the UCDP data. Retrieved from <http://www. ucdp.uu.se/gpdatabase/gpregions.php?regionSelect=5-Southern\%20Americas $>$. 
A point worthy of adding to the UCDP analyses refers to the low participation of South American countries in conflicts, which in principle can lead one to believe that this region would be peaceful.

The definition of War $\mathcal{E}^{2}$ Minor Conflict can be described as the existing or already over direct armed conflict between two or more states, conflicts which can be considered as low intensity conflict (intrastate conflicts) or as high intensity conflict (interstate conflicts). One realizes a large participation in this category from Colombia and Peru in the years established (Uppsala University 2013). The UCDP prompts that in the mid-1960s several left-bank groups emerged initiating an armed struggle against the government, such as the Revolutionary Armed Forces of Colombia (RAFC), the National Liberation Army (Spanish: Ejército de Liberación Nacional, ELN), the Popular Liberation Army (Spanish: Ejército Popular de Liberación, EPL), and the 19th of April Movement (M-19). According to the database, both sides are targeting civilians, despite that they also mention they are in support of those (Uppsala University 2013). The Colombian case is quite interesting due to its violence fitting as an example of War \& minor conflict as well as One-sided violence. Hence, it will be later explained in more detail how occurs the participation of the government and paramilitary groups in the last section.

Regarding Peru, it can be said that it also fits in that same category of violence, as the UCDP states that there were divisions between groups of the population, contributing to the emergence of various guerrilla groups with left-bank political orientation during the 20th century. Intrastate conflicts occurred between government and political parties during the $1950 \mathrm{~s}$ and 1960s, being unequal distribution of land the main motivation. From 1960 until the 1980s, a military junta has imposed some land reforms in the country, which were deemed inadequate by the left-bank opposition groups. As result it contributed to a new intrastate conflict between government and left-bank groups, initiated in 1981 and finalized in 1999, and back to being active again in 2007.

With the capture of one of the founding leaders of these groups, Sendero Luminoso (SL), the group eventually became ideologically and geographically divided. Florindo Eleuterio Flores Hala, known as Comrade Artemio, became leader of the SL with the capture of Abimael Guzmán and announced in 2011 that the armed struggle had ended, but that the political struggle would continue. However, the military presence of the SL still worries the Peruvian government as it persists in rural areas of 
the country. Another fact mentioned about this country is the fact that in 1995 Peru and Ecuador fought a brief skirmish due to problems of border demarcation in the area of the Cordillera del Condor. After a few weeks a ceasefire mediated by Brazil was signed, and although tensions between the two countries were still growing, a peace agreement was signed by the two sides in 1998 (Uppsala University 2013).

The Non-state conflict category is defined as the use of armed force between two organized armed groups without their belonging to the government of a state. This type of violence, according to the UCDP, results in at least 25 deaths a year. The most interesting detail in this section is that one sees a null participation of the countries of South America (Uppsala University 2013).

One-sided violence is characterized as the use of armed force by one government or by a formally organized group against civilians. This kind of violence, according to the UCDP, also results in at least 25 deaths a year - extrajudicial executions in government facilities, however, are excluded from this category. One can note that there is a grand participation of Colombia in this category as well, but now with a small share of Guyana (Uppsala University 2013). The UCDP mentions that the Colombian government has been involved in intrastate conflicts with different armed groups since the turbulent period known as "La Violencia", and in that time the state had committed acts of unilateral violence against civilians. According to human rights organizations, such violence would disguise the failure of the Colombian government in distinguishing civilians and combatants (Uppsala University 2013). Moreover, the government is often accused of collaborating with paramilitary groups - also known as paras - created in the 1980 s by large landowners and drug traffickers. These groups were intended with the aim to combat left-bank guerrillas of the ELN and the RAFC. The paras have also generated violence against civilians in areas where the domination of the guerrillas would be weak. In short, the government would have support to commit these acts, in addition to the support of the paramilitaries also the support of militaries and policemen (Uppsala University 2013).

Now on Colombian guerrillas, they grew increasingly due to kidnappings and the illegal drug trade. There were attempts to influence the decisions taken by the government through attacks whose targets were government officials or civilians. At this point, the RAFC (Revolutionary Armed Forces of Colombia) have a prominent role, because this was the 
group from the guerrilla groups that participated in intrastate conflicts against the government that became more important.

As for Guyana: according to UCDP, the problem that this state faces and that falls under the category of unilateral violence is the existence of Buxton, group involved in numerous kidnappings, murders and robberies among the Guyanese population since 2002. In 2006 this gang assassinated the Minister of Agriculture Satyadeow Sawh; in 2008 it clashed with the police and attacked civilians in an even larger scale than previous years, resulting in at least 29 deaths (Uppsala University 2013).

From the view of UCDP one can also affirm that considering the concepts presented by Galtung there would be a predominance of negative peace in South America. That is to say, even without a direct armed conflict between the major South American countries, violence still has a strong presence in the region. The structural violence would be also present in the case of Colombia and Peru, being generated by the violent socio-historical context that permeated their recent history.

Regarding the violence approach, one can also realize that in all three cases there was a greater focus on addressing violence by the security approach rather than the peaceful approach. This detail, according to Galtung, does not help solving the problem of violence in an effective manner, and consequently achieving positive peace.

\section{THE FUND FOR PEACE (FFP) DATABASE AND ITS DEFINITIONS ON SOUTH AMERICA}

As stated by the Fund For Peace (2013), internal conflicts and mass violence emerged in several states with the end of the Cold War. Even presenting differences between each dynamic, they are the result of social, economic and political pressures that were not administered by legitimate representative institutions. Weak and failed states represent currently a major challenge for the international community as these pressures practiced against a fragile state may create serious damage not only to this state and its people, but also to other countries participating in the international arena (Fund For Peace 2013).

Also according to the FFP, the flaws of weak and failing states may arise due to problems of identity groups, characterized by language, religion, nationality, ethnicity and class (Fund For Peace 2013). The Failed States Index, created by the FFP, seeks to make an assessment beyond the 
knowledge of the specialized area, through the interdisciplinary combination of qualitative research with quantitative methodologies. The indicators are based on social, economic, political and military fields (the two latters united in the same category), and yet subdivided into other categories. $^{2}$

The position of each South American country in the FFP is determined by the sum of the notes (ranging from 1 to 10) of sub-indicators for each of the three categories above. For the purposes of this chapter, it will be held a general analysis consistent with the social, economic, political and military indicators (a detailed analysis of each category in every South American state would excessively extend the text).

According to the methodology of FFP, the lower a country's position in the ranking the higher their safety; a low score in the three indicators indicates that the country has few or no such problem.

In the years between 2006 and 2009, it is noticed that most South American countries with the exception of Guyana and Suriname that have not had their data recorded are characterized by FSI as close to the category "Warning" (except Colombia, which is framed in this category). Considered safer only Argentina, Uruguay and Chile that are in the category "Moderate". Thus, it can be said at first that the South American region during this period had a high rate of violence - mainly the structural kind, in line with Galtung's vision.

According to social indicators, there is a very noticeable variation among South American countries (with the lowest note being 1.0 and the highest being 9.1). It is worth noting that Colombia, Bolivia, Ecuador, Venezuela and Peru are considered as the top five and all of them are in the category "Warning", being those with the highest problems of this kind. Although other countries appear in this category, it can be seen that the result of other indicators contributed so that the occupied position were not so high according to social indicators (e.g., Brazil and Paraguay).

Considering economic indicators (UED and ECO), one can notice that those five countries aforementioned also feature plenty of challenges in this area. Of the three categories the economic sphere was the main challenge faced by the region. The top five in the ranking, in addition to social problems showed major problems with economic development.

2. For further information on the methodology, see Fund For Peace (2013). 
As for the political and military indicators in this field, as well as social indicators, there is a wide variation between countries in the region (with the lowest note being 1.0 and the highest 9.2). Nevertheless, it is worth mentioning that Colombia and Venezuela are the countries with the highest values in that category, which corroborates to the fact that these states are known for their problems in the political and especially military areas.

There was an improvement in the economic indicators in 2010, although the change in the average value was small if compared to 2009. The political and military indicators 2010 have also showed improvements in relation to the years 2006, 2007 and 2009. As for 2008, according to the indicators, some countries have improved their performance, but others managed to worsen them.

Finally, regarding the year 2011, there was no change compared to 2010. As to the indicators, the same can be said: the values and its performance are the same as the previous year.

\section{FINAL CONSIDERATIONS: COMPARATIVE ANALYSIS OF THE UCDP AND THE FUND FOR PEACE (FFP) GENERAL DATA CONSIDERING THE CONCEPTS USED BY GALTUNG}

As stated in the introduction, the results here presented are preliminary taken from a research in development. Nevertheless, it can be stated that in relation to their methodologies, it is clear that the methods of analysis differ widely from the UCDP to the FFP. The first focuses almost exclusively in armed conflicts, while the base of the FFP includes a wider variety of variables and it can better display the position of South America.

Regarding the FFP data, just like the UCDP, it confirms the views of Medeiros (2008) and Alsina Jr. (2009) that there is greater instability in the Andean region stretching from Peru to Venezuela-Guyana border. However, even countries that are at the Arc Stability - where the Southern Cone can be emphasized - would not be considered safe. In accordance to the selected years (2006-2011), most of them were placed in the "Warning" category, which means actually that the region is at the level where states are presented with limited institutionalization in some areas and serious difficulties to ensure the safety of its population.

The FFP data provokes, though, further reinforcement to the thought of Johan Galtung towards a preponderance of negative peace, even if there are no conflicts between those states. In other words, although the 
use of direct violence among the states might not be a constant there is a predominance of structural violence in the region.

The data are important to show us that even at different levels South America can be regarded as a region in which violence is inherently structural. Those methods that focus on the use of the security approach can be appointed as insufficient to solve that problem. On the contrary: it is through peace studies and peace approach that the region's problems will be solved, because, as noted by the methodology of FFP, the social, economic and political fields are closely linked, and they influence the existence of violence. 


\section{RESUMO}

O presente artigo pretende introduzir uma discussão em torno da Segurança na América do Sul com o argumento de que não vivemos necessariamente em uma zona de paz. A (quase) ausência de conflitos interestatais nas últimas décadas não se reflete em uma paz para a população comum de uma região que tem a infelicidade de apresentar um dos maiores índices de homicídios no mundo. Para apresentar os argumentos, começaremos com o debate teórico proporcionado pelos Estudos sobre a Paz, no qual Johan Galtung é um dos principais expoentes. Em seguida, mostraremos como algumas das entidades que são referência na análise de conflitos internacionais - a The Fund for Peace e a Universidade de Upsalla, Suécia - têm compreendido a região sul-americana no período de 2006-2012, na qual constam os dados mais atualizados da região. A análise dos dados dessas entidades demonstram que a violência predominante na América do Sul é eminentemente estrutural, fato que limita uma análise fundamentada em um exame focada somente nos atores estatais.

Palavras-chave: Estudos sobre paz. Violência. América do Sul. Análise de conflitos.

\section{ABSTRACT}

This article intends to introduce a discussion on Security in South America following the argument that this region do not necessarily correspond to an area of peace. The (almost) absence of interstate conflicts in recent decades does not reflect peace on the common people of a region that has the misfortune to present one of the highest homicide rates in the world. To acquaint with the arguments the article initiates with the theoretical discussion provided by the Peace Studies, in which one of the leading exponents is Johan Galtung. Then, it is shown how some of the entities that are reference in the analysis of international conflicts - The Fund for Peace and the Uppsala University, Sweden - have understood the South American region from 2006 to 2012, a period that represents the most current data on the region. The data 
analysis provided by those entities demonstrate that the prevailing violence in South America is mainly structural, and that represents a limitation towards a reasoned analysis in an examination focused only on state actors.

Keywords: Peace studies. Violence. South America. Conflict analysis.

\section{REFERÊNCIAS}

Alsina Jr, João Paulo Soares. 2009. Política Externa e Poder Militar no Brasil: Universos Paralelos. Rio de Janeiro: Editora FGV.

Fund For Peace. Indicators of Fund For Peace. 2013. Disponível em <http://ffp. statesindex.org/indicators> Acessado em: 24 de junho de 2013.

Methodology. http://ffp.statesindex.org/methodology. Acessado em: 24 de junho de 2013.

Galtung, J. Violence, Peace and Peace Research. In Journal of Peace Research. 1969. 6 (3). (p. 167-191).

Grewal, Baljit S. 2003. Positive and Negative Peace. School of Social Science, Auckland University of Technology. (p. 1-7).

Medeiros Filho, Oscar. 2008. Geografia política sul-americana e percepções das agências de defesa. Anais do Encontro Nacional da Associação Brasileira de Estudos de Defesa. V.o2. (p. 1-13).

Serbín, Andrés. 2008. Paz, violência y sociedade civil en América Latina y el Caribe. Introducción a algunas nociones básicas. In: Serbín, Andrés (Coord.). Construcción de paz y diplomacia ciudadana em América Latina y el Caribe. $1^{\mathrm{a}} \mathrm{Ed}$.

Uppsala Conflict Data Program (UCDP). UCDP Data Base (2013). http://www. ucdp.uu.se/gpdatabase/gpregions.php?regionSelect=5-Southern\%20Americas. Acessado em: 14 de junho de 2013.

UCDP Definitions (2013). http://www.pcr.uu.se/research/ucdp/

definitions. Acessado em: 14 de junho de 2013.

Recebido em: 10/04/2014. Aprovado em: 02/06/2014. 